\title{
Seralarda Isı Kaybına Neden Olan Yapısal Sorunların Termal Kamera ile Belirlenmesi
}

\author{
Ali ÇAYLI ${ }^{1}$, Adil AKYÜZ ${ }^{2}$, A. Nafi BAYTORUN ${ }^{3}$, Sait ÜSTÜN ${ }^{2}$, Sedat BOYACI ${ }^{4}$ \\ ${ }^{1}$ KSÜ, Türkoğlu Meslek Yüksekokulu, Kahramanmaraş \\ ${ }^{2}$ KSÜ, Ziraat Fakültesi, Biyosistem Mühendisliği Bölümü, Kahramanmaraş \\ ${ }^{3}$ ÇÜ, Ziraat Fakültesi, Tarımsal Yapılar ve Sulama Bölümü, Adana \\ ${ }^{4}$ AEÜ, Ziraat Fakültesi, Biyosistem Mühendisliği Bölümü, Kırşehir
}

Geliṣ (Received): 03.07.2015

Kabul (Accepted): 07.01.2016

\begin{abstract}
ÖZET: Tarımsal üretim yapıları olan seralarda ısıtma yapılarak daha fazla ve aynı zamanda kaliteli ürün alınabileceği bilinmektedir. Soğuk mevsimlerde ssıtılarak üretim yapılan seralarda, 1sıtma girdileri üretim giderleri içerisinde önemli bir yer tutmaktadır. Seralarda 1sıttma giderlerinin en az düzeye indirilmesi ve tüketilen enerjiden en fazla etkinin elde edilmesi amacıyla teorik olarak öngörülen ve uygulanan bazı 1sı tasarruf önlemleri, yeterli sızdırmazlık ve yalıtımın yapılmamasından dolayı istenilen etkiyi gösterememektedir. Bu amaçla, seralardaki yapısal sorunlardan kaynaklanan ısı kayıplarının belirlenmesi için termal görüntüleme yönteminin kullanılabilirliği bu çalışma ile irdelenmiştir. Termal kamera ile seralarda isıtma yapılırken alınan görüntüler, analiz yazılımıyla detaylı olarak incelenerek ve 1sı kaybına neden olan sorunlar belirlenmeye çalışılmıştır. Elde edilen sonuçlar, 1sı kayıplarına neden olan yapısal sorunların termal görüntüleme tekniği ile tespit edilebildiğini ve bu sorunların en çok kapı altları ve kenar boşlukları, havalandırma penceresi kenarlarındaki açıklıklar, örtü malzemesinin çatı-ön duvar ve çatı-yan duvar birleşim noktaları ile iyi izole edilmeyen subasman betonunda olduğu göstermiştir.
\end{abstract}

Anahtar Kelimeler: Termal görüntüleme, Seralar, Isı kaybı, Isı yalıtımı, Isı tasarrufu

\section{Determination of Structural Problems Causing Heat Loss with the Thermal Camera in Greenhouses}

ABSTRACT: It is widely known that it is possible to harvest more and high quality products from greenhouses, which are agricultural production structures. Heating costs occupy an important position in overall production costs since greenhouses are heated in order to harvest product during winter. Various theoretical heat saving methods which are applied in order to minimize heating costs and maximize efficiency in greenhouses do not reach intended levels due to insufficient sealing and insulation. In this respect, this study focuses on the feasibility of thermal imaging in order to identify heat losses due to the structural problems in greenhouses. Images obtained from thermal cameras in greenhouses were analyzed via analysis software and problems that may lead to heat losses were identified. The findings demonstrate that thermal imaging technique can identify structural problems which lead to heat losses and that these problems stem from holes on the bottom and sides of the doors, holes on the ventilation window, holes at the junction point of covering-front wall and covering-side wall, and insufficiently insulated subbasement concrete.

Key Words: Thermal imaging, Greenhouses, Heat loss, Thermal insulation, Heat savings

\section{GİRIȘ}

Serada 1sıtma yapılması yalnızca iç sıcaklığın bitki istekleri seviyesine getirilmesinin yanında sera iç ortam neminin kontrol edilmesinde de önemli bir rol oynamaktadır. Özellikle sabah erken saatlerde çok yüksek seviyelere ulaşan sera içi oransal nemi, birçok bitki hastalıklarına sebep olmakta ve bu hastalıklarla mücadele için kullanılan ilaçlar hem çevreye hem de insan sağlığına zarar vermektedir.

Seralarda 1sıtma sistemleri pahalı yatırımlardır. $\mathrm{Bu}$ sebeple planlama aşamasında uygun ısıtma sistemi ve kapasitesinin belirlenmesi yatırım giderlerini azaltarak üreticilerin gelirlerini artıracaktır.

Soğuk mevsimlerde sera iç hacminin bitkilerin isteklerine uygun değerlerde 1sitılması için yapılan harcamalar, tüm üretim harcamalarının yarısından fazlasını oluşturmaktadır. Isıtılan seralarda yapılan bu harcamaları en aza indirebilmek için 1s1 korunumu önlemlerine dikkat etmek gerekir (Yağcıoğlu, 2009).
Seralarda kış döneminde tüketilen enerjinin \% 70‘den fazlası sera örtü malzemesinden kaybolmaktadır. $\mathrm{Bu}$ nedenle örtü malzemesi yoluyla oluşan 1sı kaybının doğru şekilde analitik olarak tahmin edilmesi, seranın enerji tüketiminin tahmin edilmesinde kilit noktadır (Zhang ve ark.,2008).

Işıma kayıpları, toplam örtü 1sı kayıplarının başlıca bileşenidir. Gece boyunca toprak bir 1S1 kaynağı olarak önemli rol oynamaktadır. Orta ısıtma rejiminde 1 şıma kayıplarının 1sıtma girişinden daha yüksek olduğu ve ısı girişinin artmasının konvektif kayıpların göreceli olarak önemini artırmaktadır (Baille,2006).

Günümüzde sürekli olarak enerji tasarrufu sağlayan sera konstrüksiyonları üzerinde çalışmalar yapılmaktadır. $\mathrm{Bu}$ amaçla seralarda 1sı kaybının azaltılması için; yalıtımlı örtü malzemesi (çift katlı), 1sı kaybına neden olan yapı elemanlarının azaltılması (su olukları), istenmeyen açıklıklardan oluşan 1Sı kaybının azaltılması, örtü alanının, sera taban alanına oranının 
olanaklar ölçüsünde küçültülmesi gereklidir (Baytorun,1996).

Sızma enerji kayıpları yapı ve kaplama malzemesi içindeki açıklıklar ve aynı zamanda dış rüzgâr hızı ve yönü ilgilidir. Açıklıkların miktarı, boyutu ve yeri bu sızma kayıplarını etkiler. Bunlar, giriş kapıları, ısıtıcı emme/egzoz açıklıkları ve fan/vantilatör açıklıklarıdır. Sizma doğrudan örtü malzemesinin bir film tabakası şeklinde veya cam ya da sert panel gibi modüler sistem olup olmadığına yüksek derecede bağlıdır. İkinci durumda gaz ve nem alışverişi sağlayan birçok kenara sahip olacaktır (Giacomelli ve ark,1993).

Çok sayıda ek yerleri sızma kayıplarını artırmaktadır. Bir serada 1s1 sızma kayıpları hacimsel hava değişimi ile ifade edilir. Sızma oranları yekpare plastik örtülerde saatte 0.5 hacimsel hava değişimi (VAC $\mathrm{hr}^{-1}$ ) iken yeni cam kaplamada 0.75-1.5 VAC $\mathrm{hr}^{-1}$ arasında olmak üzere geniş aralıkta olabilir (Aldrich ve Bartok, 1989).

Termografi, termal görüntüleme veya termal video, kızılötesi görüntülemenin bir çeşididir. Termografik kameralar elektromanyetik spektrumun kızılötesi bölümündeki (kabaca 900-14,000 nanometre veya 0.9$14 \mu \mathrm{m})$ elektromanyetik 1 şınımı tespit ederler ve bu ışınımdan resimler oluştururlar. Kızılötesi 1 şınım sıcaklıklarına göre tüm cisimlerden salınır, Kara cisim 1şıması kanununa göre, termografi görünür aydınlatma olmadan cisimlerin görünebilmesini sağlar. Bir cisim tarafından salınan 1şınımın miktarı sıcaklık arttıkça artar, bu yüzden termografi sıcaklıktaki farkları görmemizi sağlar. (Çalışan ve ark.,2011).

Termografinin kökeni İngiliz fizikçi William Herschel'in görünür spektrumda koyu kırmızı dışında, daha sonra kızılötesi olarak adlandırılan, gözle görülemeyen 1şı̆̆ı keşfettiği 1800'li y1llara kadar gitmektedir. Sonraki yıllarda, aralarında Macedonio Melloni, Gustav Kirchhoff, Clark Maxwell, Joseph Stefan, Ludwig Boltzmann ve Max Planck'inda bulunduğu birçok fizikçi, tam termal radyasyon spektrumunun enerji dağılımını anlama üzerinde çalışmışlardır (Astarita ve ark., 2000). Konvektif 1S1 transfer ölçümlerinde, çeşitli yönleriyle detaylı analizler yapmak için, termografiden yararlanılabilmektedir (Carlomagno ve ark., 2010).

Termografi, yüzeylerin 1sı akışını görselleştirmenin yanı sıra, konvektif ısı akıları ölçmek için sürekli veya geçici olarak verimli bir şekilde kullanılan tekniktir (Carlomagno ve ark.,1998)

Termal kameralar ilk defa askeri amaçlar için 1960'lı yıllarda üretilmeye başlanmıştır. İlk radyometrik termal kameralar, 1970'deki enerji krizi sırasında hükümet desteği ile AGA ve Bofors adlı İsveçli iki firma tarafından geliştirilmiştir (Carlomagno ve ark., 2010).

1967 y1lında üretilen AGA Thermovision 680SWB makinesi ile Thomann ve Frisk (1968), mach sayıs1 M = 7 olan bir rüzgâr tünelinde elastomerik paraboloidin yüzeyindeki sıcaklık dağılımını ölçmüşlerdir.

Termal kameralar, sıcaklıkları uygun termal sensör ve dönüştürücülerle yapıldığından dolayı standart dönüştürücülerle karşılaştırıldığında bazı noktalardan konvektif 1 sı transfer ölçümlerinde avantajlı olduğu görülmektedir (Carlomagno ve ark., 2010).

Şeffaf olmayan tüm cisimler, mutlak sıcaklığın $\mathrm{T}>0$ olması durumunda yüzeylerinden 1şınım yayarlar. Belli sicaklıkta en yüksek miktarda enerji yayan cisme siyah cisim denir (Carlomagno ve ark., 2010). Bu ışınım miktarı cismin özelliklerine veya depoladığı 1S1 miktarına göre farklılıklar gösterir. Termal kameralar cisimlerin yaydığı bu 1S1 1şınımlarını algılayarak renk haritaları oluştururlar.

Mimari yapılarda uzaktan görüntüleme sistemi olarak kızılötesi termografi büyük yüzeylerin hızlı bir şekilde değerlendirmesi için kullanılabilmektedir (Meola ve ark.,2005).

Doğru kullanılması durumunda termal kameralar, duvarlar ve yüzeylerdeki 1sı akışının ölçülmesinde çok güçlü bir optik araçtır. Akışkanlar dinamiği ve 1s1 transferi gibi konularda çalışan araştırmacılara geniş bir yelpazede deneysel firsatlar sunmaktadır. Ayrıca elektronik, tahribatsız malzeme testleri, Nem tespiti, otomasyon, tıp, enerji tasarrufu, tarım, akıllı bakım ve çevre uygulamaları gibi daha bir çok alanda kullanılabilmektedir (Carlomagno ve ark., 2010).

$\mathrm{Bu}$ çalışmada, termal kamera ile elde edilen fotoğrafların analiz yazılımıyla incelenmesi ile serada oluşan sızma 1Sı kayıplarının kaynağı ve sera elemanları ile toprak yüzeyinin, sera 1s1 dengesine etkisi ortaya konmuştur.

\section{MATERYAL ve YÖNTEM}

Araştırma Kahramanmaraş Sütçü İmam Üniversitesi, Ziraat Fakültesi uygulama alanında bulunan kuzey-doğu güney-batı doğrultusunda bulunan 37.591500 enlem, 36.803000 boylam koordinatlarında, denizden yüksekliği $468 \mathrm{~m}$ olan seralarda yapılmıştır. Araştırma seraları $20 \mathrm{~m}$ uzunluğunda, $7.5 \mathrm{~m}$ genişliğinde ve $3 \mathrm{~m}$ yüksekliğindedir. Galvanizli çelik malzemeden imal edilen ve çatıdan havalandırma yapılan seraların teknik özellikleri Çizelge 1'de verilmiştir. 
Çizelge 1. Araştırma seraları teknik özellikleri

\begin{tabular}{|l|c|c|c|}
\hline \multicolumn{1}{|c|}{ Teknik Özellikler } & SERA-1 & SERA-2 & SERA-3 \\
\hline Uzunluk $(\mathrm{m})$ & 20.0 & 20.0 & 20.0 \\
\hline Genişlik $(\mathrm{m})$ & 7.5 & 7.5 & 7.5 \\
\hline Yan duvar yüksekliği $(\mathrm{m})$ & 3.0 & 3.0 & 3.0 \\
\hline Mahya yüksekliği & 5.0 & 5.0 & 5.0 \\
\hline Taban alanı $\left(\mathrm{m}^{2}\right)$ & 150 & 150 & 150 \\
\hline Örtü yüzey alanı $\left(\mathrm{m}^{2}\right)$ & 352.6 & 352.6 & 352.6 \\
\hline Katkılar & UV+IR+EVA & UV+IR+EVA & UV \\
\hline Örtü malzemesi kalınlığı $(\mathrm{mm})$ & 0.3 & 0.3 & 4.0 \\
\hline Kullanım ömrü & 36 Ay & 36 Ay & 120 Ay \\
\hline Havalandırma alanı $\left(\mathrm{m}^{2}\right)$ & 30 & 30 & 30 \\
\hline Havalandırma tipi & Doğal & Doğal & Doğal \\
\hline Örtü malzemesi & Tek kat PE & Çift kat PE & Polikarbonat \\
\hline
\end{tabular}

Bir kızılötesi kameranın performansı, geleneksel olarak termal duyarlılık, tarama hızı, görüntü çözünürlüğü ve yoğunluk çözünürlüğü açısından değerlendirilmektedir (Carlomagno ve ark., 2010). Kızılötesi termal fotoğraflar FLIR T200 model kamera ile çekilmiştir. Kamera $60 \mathrm{~Hz}$ çerçeve oranında -20 ile $650{ }^{\circ} \mathrm{C}$ arasında sicaklığ 1 algılama, 7.5 ile $13 \mu \mathrm{m}$ tayf aralığında ve \% 2 doğruluk oranında, $30{ }^{\circ} \mathrm{C}$ 'de $0.045^{\circ} \mathrm{C}$ çalışma hassasiyetinde, 320 × 240 piksel boyutunda ve toplam 76,800 piksel fotoğraf çekme kapasitesine sahiptir. Görüş alanı açısı $25^{\circ}$ x $19^{\circ}$ ve odaklama aralığ 1 0.4 m'dir. Analiz yazılımı olarak FLIR Quickreport yazılımı kullanılmıştır. Bu yazılımla cihazdan aktarılan fotoğraflar yüksek çözünürlükte incelenebilmekte, malzeme ve dış ortam bilgileri girilerek daha ayrıntılı analiz yapılabilmektedir.

Sicaklık ve nem ölçümleri HOBO U12 model veri kaydediciler ile yapılmıştır. Veriler her 15 dakikada bir, sera içerisinde yerden $1.5 \mathrm{~m}$ yükseklikte, sera dışında ise iklim siperi içerisine yerleştirilen veri kaydediciden alınmıştır.

Seraların 1sitılmasında, her bir kademede $8 \mathrm{kWh}$ 1sıtma kapasitesine sahip üç kademeli, toplamda 24 $\mathrm{kWh}$ 1sitma kapasiteli, sicak hava üflemeli 1sitıcılar kullanılmıştır. Isıtıcıların teknik özellikleri Çizelge 2'de verilmiştir. Isıtıcı üzerinde bulunan kontrol panosunda yer alan zaman ayarlı röle ve termokupl kontrol rölesi ile 1 sitıcı çalışma zaman aralığı ve istenilen iç sıcaklık değerleri kontrol edilmiştir.

Çizelge 2. Sıcak hava üflemeli ısıtıcıların teknik özellikleri

\begin{tabular}{|l|c|}
\hline \multicolumn{1}{|c|}{ Teknik Özellikler } & Değer \\
\hline Toplam ısıtma kapasitesi & $24 \mathrm{kWh}$ \\
\hline 1. Kademe 1sıtma kapasitesi & $8 \mathrm{kWh}$ \\
\hline 2. Kademe 1sıtma kapasitesi & $16 \mathrm{kWh}$ \\
\hline 3. Kademe 1sıtma kapasitesi & $24 \mathrm{kWh}$ \\
\hline Hava debisi & $1440 \mathrm{~m}^{3} / \mathrm{h}$ \\
\hline Akım değeri & $27 \mathrm{Amper}$ \\
\hline Giriş voltajı & $400 \mathrm{~V} / 50 \mathrm{~Hz}$ \\
\hline Hava çıkış hızı & $8.9 \mathrm{~m} \cdot \mathrm{s}^{-1}$ \\
\hline 1. Kademede hava çıkış sıcaklığı & $48^{\circ} \mathrm{C}$ \\
\hline 2. Kademede hava çıkış sıcaklı̆̆1 & $85^{\circ} \mathrm{C}$ \\
\hline 3. Kademede hava çıkış sıcaklığı & $115^{\circ} \mathrm{C}$ \\
\hline
\end{tabular}

Çalışmada, termal kameralardan alınan görüntülerdeki 1sı kayıplarının olduğu yerlerin tespit edilmesinde renk skalasındaki değerler kullanılmıştır. Renk skalasına göre turuncu-sarı renkler yüksek sıcaklık değerleri göstermektedir. Bu renklerin görüldüğü ek ve birleşim yerlerinde sızma 1sı kayıplarının fazla olduğu anlaşılmaktadır. 


\section{BULGULAR ve TARTIŞMA}

Şekil 1'deki görüntü, 1S1 perdeli polikarbonat örtü malzemeli serada dış ortam sıcaklığ $12{ }^{\circ} \mathrm{C}$ ve $\% 30$ oransal nem koșullarında çekilmiștir. Sekildeki renk ölçeğinde alt ve üst limit değerleri ile analiz yazılımında yapılan renk düzeltmeleri sonucunda, kesin değerleri vermemekle birlikte, 1Sı kayıpları ve sera içi sıcaklık dağılımı hakkında genel değerlendirme yapılabilmektedir. Dışarıdan çekilen termal görüntülerde 1sı sızmalarının olduğu noktalar açık renkli olarak görülmektedir.

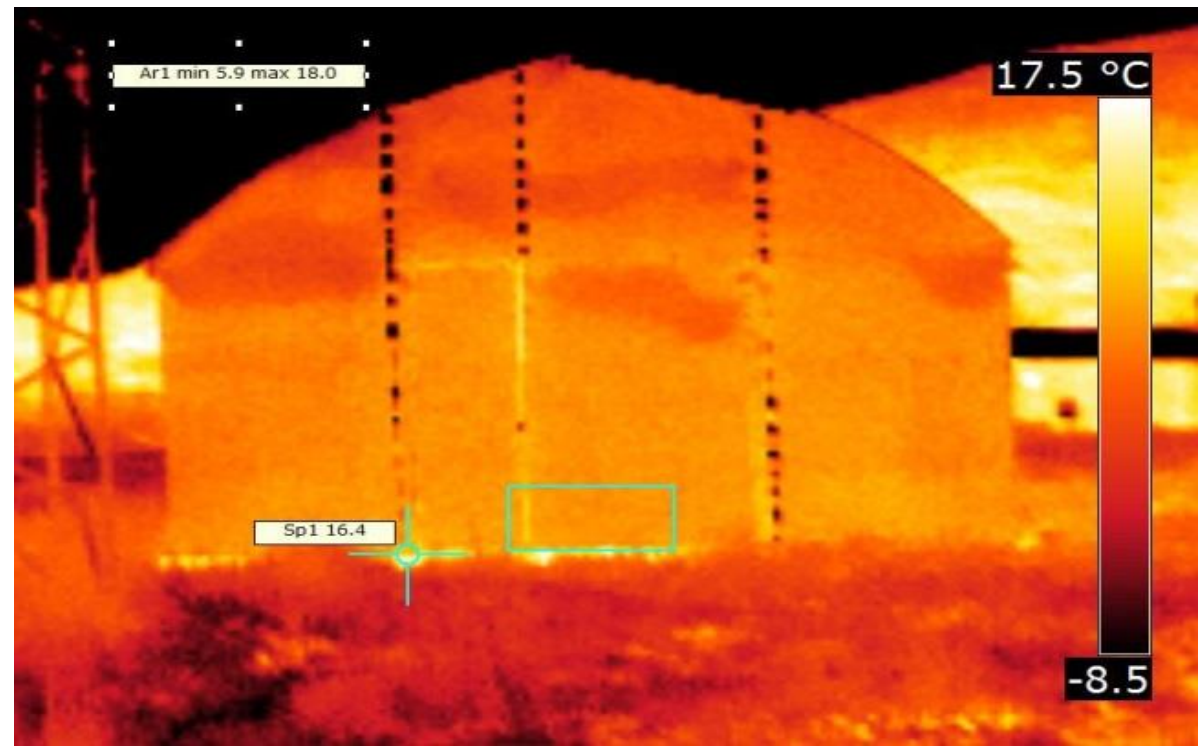

Sekil 1. Sera termal görüntüsü (renkli)

Is1 perdesi çekilen ve isıtma yapılan seralarda her zaman çatı sıcaklıkları iç sıcaklıktan $2-3{ }^{\circ} \mathrm{C}$ daha düşük olmaktadır. Sera çatı seviyesinin, alt kısımdan daha koyu renkte olması çatı seviyesi sıcaklığının daha düşük olduğunu göstermektedir. Ayrıca giriş kapısı kenarında kalan boşluklardan sızma yoluyla 1sı kaybı olduğu da açıkça görülmektedir. Şekil 1'de renkli olarak verilen resim analiz yazılımıyla çeşitli renk tonlamalarına dönüştürülebilmektedir. Şekil 2'de siyah-beyaz verilen resim incelendiğinde ise aynı şekilde 1sı sızma noktaları görülmektedir. Grileştirilen resimde (Şekil 2) açık renkler yüksek sıcaklıkları, koyu renkler ise düşük sıcaklıkları göstermektedir. $\mathrm{Bu}$ sayede gri tonlamalı resimler üzerinden de 1S1 kayıplarının gerçekleștiği yerlerin belirlenmesi olasıdır.

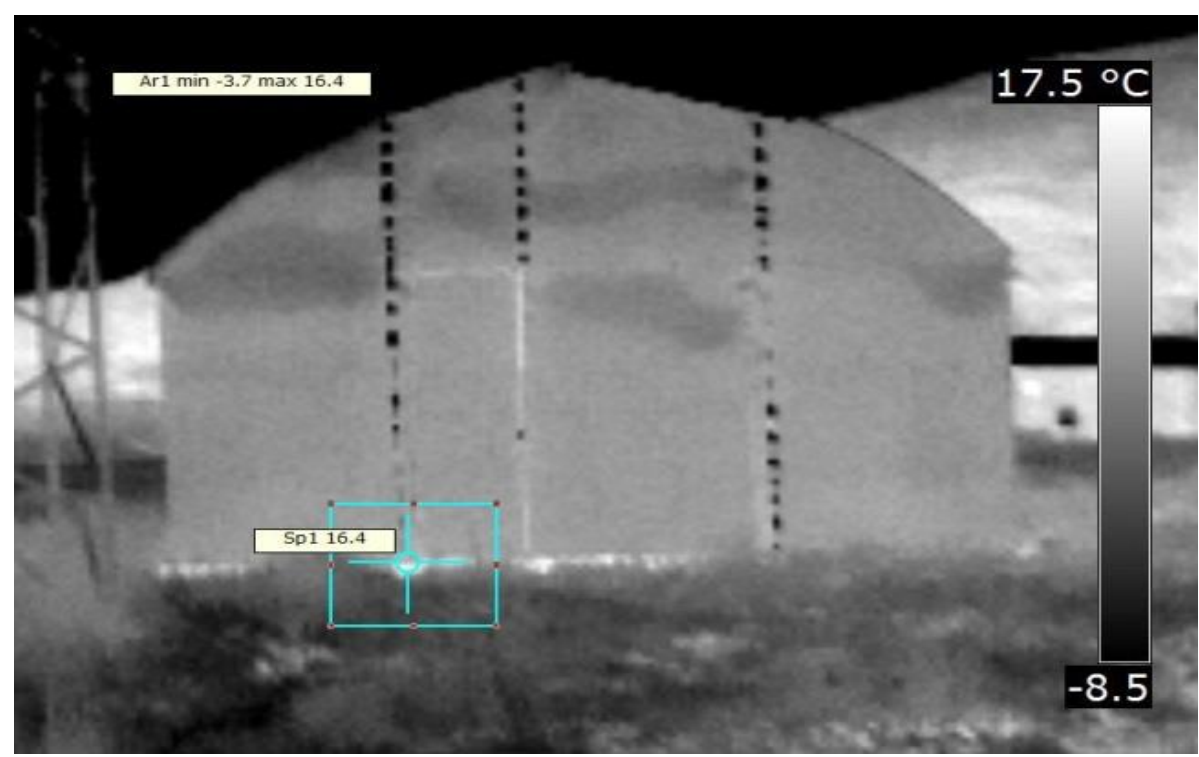

Sekil 2. Sera termal görüntüsü (siyah-beyaz)

Çatı kirişleri ile yan duvar bağlantı noktalarında da (Sekil 3) yüksek sıcaklık oluştuğu renk farklılıklarından anlaşılabilmektedir.
Ayrıca 1S1 perdesinin yan duvar üzerindeki 1S1 yalıtımına etkisi Şekil 3'de görülmektedir. Yan duvarın üst kısmından yaklaşı $1 \mathrm{~m}$ aşağı doğru resimdeki 
rengin daha koyu olduğu, ancak ön duvara kadar perdenin tam olarak kapanmadığı görülmektedir. Ön duvara kadar tam kapatılmayan 1sı perdesinin ön duvara yakın yerlerde 1S1 yalıtıma etkisinin olmadığını göstermektedir.

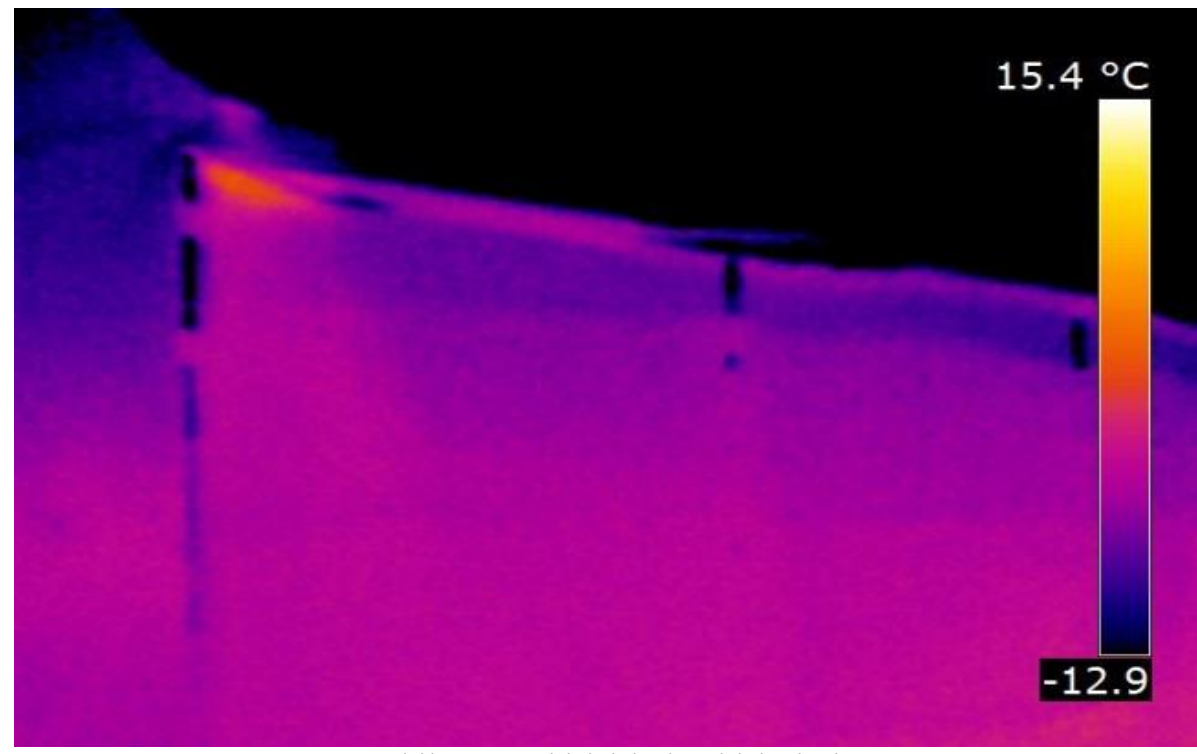

Şekil 3. Çatı kirişi-kolon birleşimi

Şekil 4'deki sera genel termal görüntüsü üzerinde 1S1 farklılıkları renk ölçeğiyle kıyaslandığında açık şekilde görülmektedir. Görüntünün çekildiği saatte dış sıcaklık $12{ }^{\circ} \mathrm{C}$, ortalama rüzgâr hızı $2 \mathrm{~m} / \mathrm{s}$ ve dış ortam oransal nem değeri \% 70'dir. Sera içinde ise yerden $1 \mathrm{~m}$ yükseklikte ölçülen sıcaklık $17{ }^{\circ} \mathrm{C}$, çatı seviyesinde sıcaklık $14{ }^{\circ} \mathrm{C}$ ve iç ortam oransal nem değeri \% 50'dir.

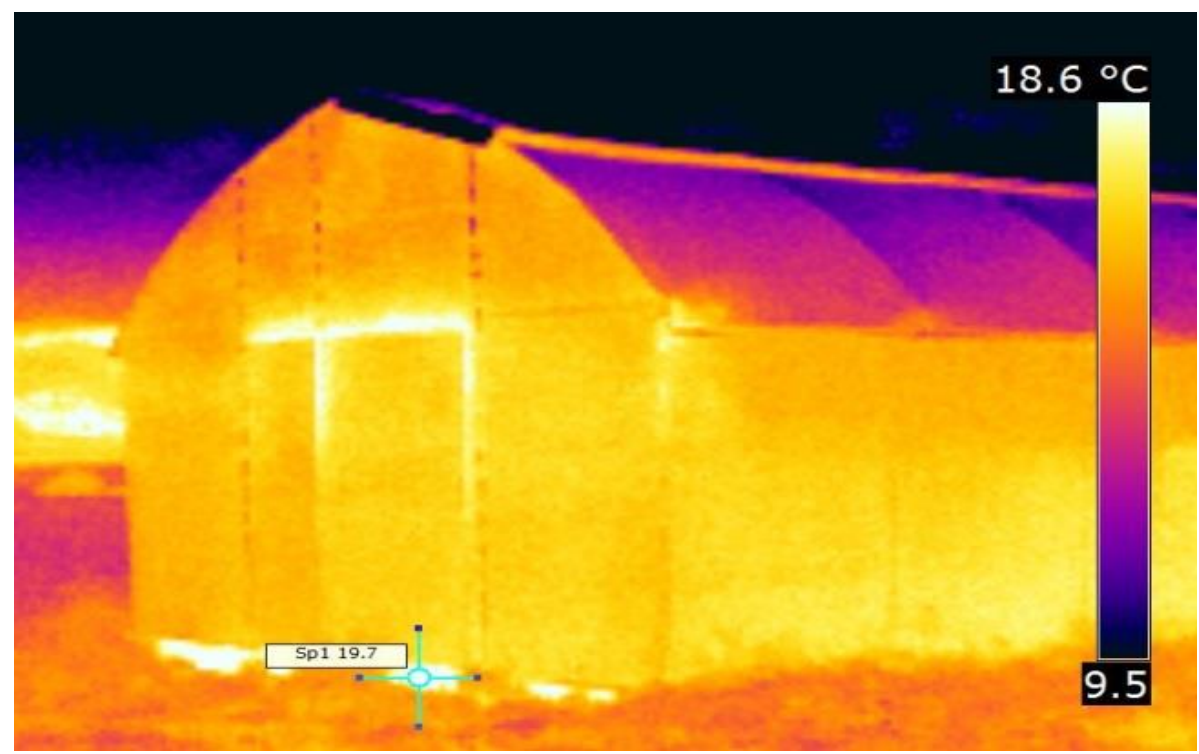

Şekil 4. Sera genel görünüş

Görüntü üzerinde sıcaklık değerleri incelendiğinde en yüksek sıcaklıkların ön kapı kenar boşluklarında ve ön subasman betonu üzerindeki bazı noktalarda olduğu görülmektedir. Ayrıca çatı havalandırma kapağı altında da çatı seviyesi sıcaklığından daha yüksek bir sıcaklık oluştuğu görülmektedir. Serada 1sı kayıplarının en fazla kapı kenar boşluklarından kaynaklandığı, aynı zamanda, çatı havalandırma kapağının hemen alt kısmında da 1s1 kaybı oluştuğu görülmektedir. Sera yan duvarında ise dikey yönde 1S1 farklılıkları olduğu görülmektedir. Sicaklığın yan duvarın alt kısmında üste göre daha yüksek olduğu, bu sicaklık farklılığının, 1s1 perdesi kullanılan serada yan duvarların alt kismında, 1s1 perdesinin kaplama yüzeyi dışında kalan alanda, 1S1 kaybının daha fazla olduğunu göstermektedir.

Şekil 5'de polikarbonat örtü malzemeli seranın subasman betonu ile yan duvarın birleşim yerinin görüntüsü verilmiştir. Bu görüntüde birleşim yerlerinde 
renk ölçeğine göre yüksek sıcaklıkların oluştuğu görülmektedir. Sera içerisindeki yüksek 1sının, bu birleşim yerlerinden dişarıya doğru sızdığı ve serada ısı kaybına neden olduğu anlaşılmaktadır. Görüntüdeki en yüksek sıcaklık değerinin $14.8{ }^{\circ} \mathrm{C}$, sera yan duvar yüzeyi üzerinde ise en düşük sıcaklık değerinin $10.8^{\circ} \mathrm{C}$, sıcaklık farkının ise $4{ }^{\circ} \mathrm{C}$ olduğu analiz yazılımı yardımıyla belirlenmiştir.

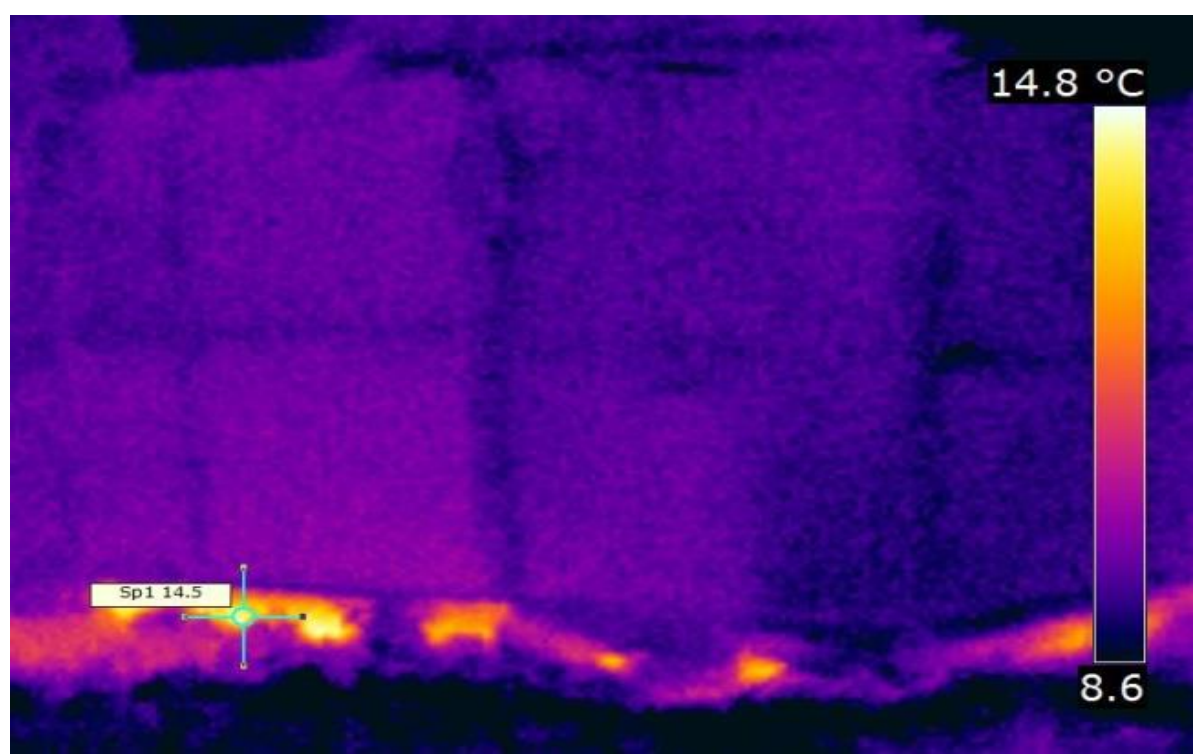

Şekil 5. Sera genel görünüş

Termal kamera ile çift kat plastik örtülü seranın yan tarafından alınan görüntü Şekil 6'da verilmiştir. Bu görüntünün analiz yazılımında incelenmesiyle ön kapı altında ve subasman betonunun ön bölümünde yüksek sıcaklıkların oluştuğu görülmektedir.

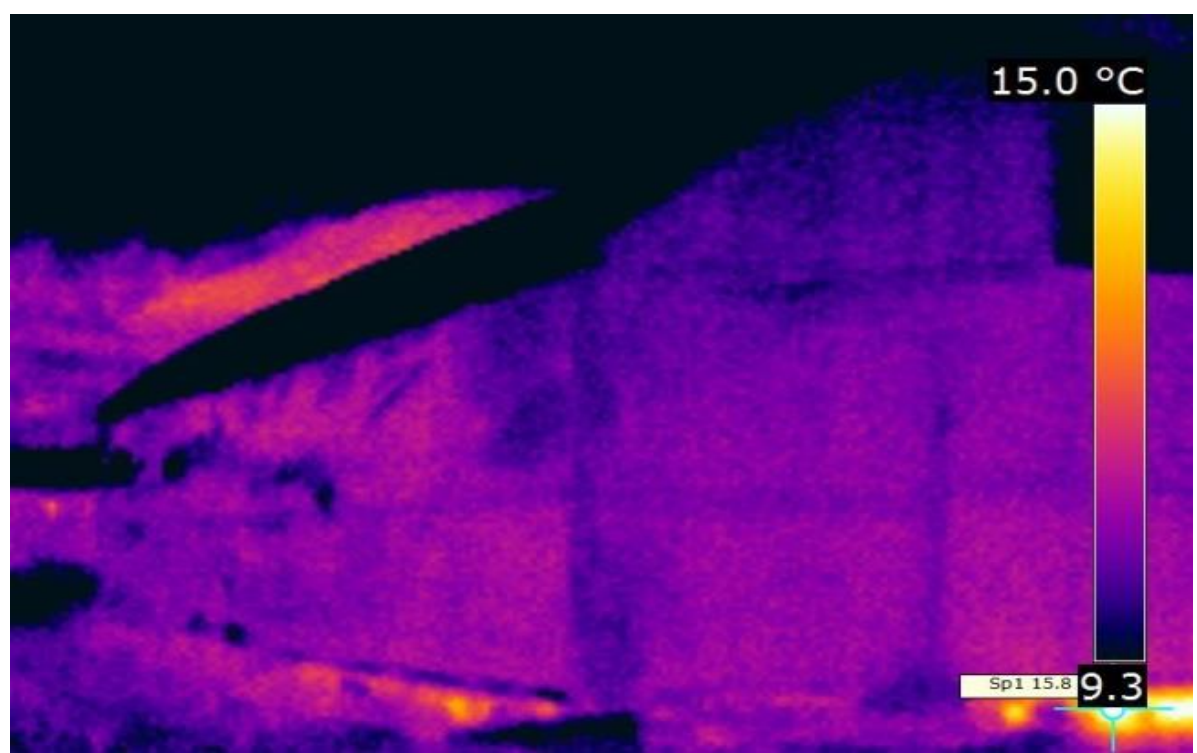

Şekil 6. Sera yan görünüş

Is1 perdesi kullanılmayan bu serada yan duvar sıcaklığının daha homojen dağılım gösterdiği görülmektedir. Ön duvarın üst kısmında ise örtü malzemesinin kaplanması sirasında klipslerden sarkan fazlalıkların kesilmemesinden dolayı iç yüzeyde bir katman daha oluștuğu ve bu bölümdeki sıcaklığının daha düşük olduğu dolayısıyla bu alandan 1sı kaybının daha az olduğu görülmektedir. Isı perdesi kullanılan serada, iç ortamdan alınan görüntü Şekil 7'de verilmiştir. Isıtma sistemi çalışır durumda olan polikarbonat serada, 1S1 perdesi üzerindeki sicaklığın yan duvarlardan daha yüksek olduğu, 1s1 perdesi üzerinde ise 1 sının orta kısımlarda kenarlardan daha yüksek olduğu görülmektedir. 


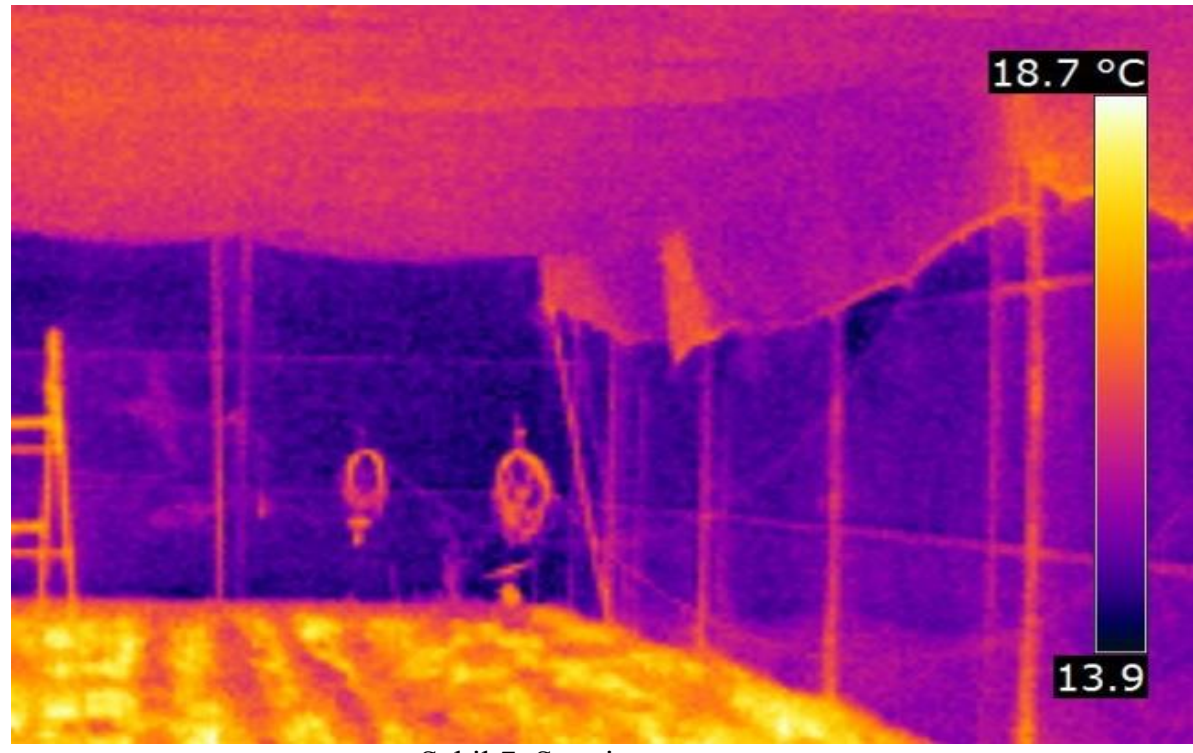

Şekil 7. Sera iç görünümü

Analiz yazılımı ile 1s1 perdesi yüzey 1sıs1 maksimum $16.4{ }^{\circ} \mathrm{C}$, minimum $15.2{ }^{\circ} \mathrm{C}$ ve polikarbon örtü malzemesi iç yüzey sıcaklı̆ğ maksimum $15.1{ }^{\circ} \mathrm{C}$, minimum $14.3{ }^{\circ} \mathrm{C}$ olduğu ölçülmüştür. Bu durum seraya verilen ısının çatıya doğru akışının ısı perdesi tarafından engellendiği ve 1S1 perdesi yüzeyi üzerinde, özellikle orta kısmında, 1sının yükseldiğini göstermektedir.

Sera zemin sıcaklığı ve bitki sıcaklığı da termal fotoğraf ile belirgin şekilde görüntülenebilmektedir. Marul (Lactucasativa) bitkisi yetiştirilen seranın zemin görüntü Şekil 8'de verilmiștir. Görüntüde bitki sıra aralarının daha açık renkli görülmesinden, serada gün boyu güneş radyasyonu etkisi ile ısınan toprağın, gece boyunca sera içerisine termal radyasyon yayarak, sera iç ortam ısısına katkı sağladığı anlaşıımaktadır.

Analiz yazılımı ile bitki sıra aralarında toprak yüzey sıcaklığı maksimum $18.0{ }^{\circ} \mathrm{C}$, minimum $16.2{ }^{\circ} \mathrm{C}$ olarak ölçülmüştür. Toprak yüzey sıcaklığının geniş bir aralıkta değişmesi, yüzeydeki yabancı otlar ve bitkilerden kaynaklanmaktadır. Aynı zamanda serada yalıtım yapılmayan subasman betonunun sera içindeki yüzeyi üzerinde yüksek sicaklık oluştuğu, oluşan bu yüksek sıcaklığın, seradan kondüksiyon yoluyla is1 kaybına neden olduğunu göstermektedir (Şekil 8).

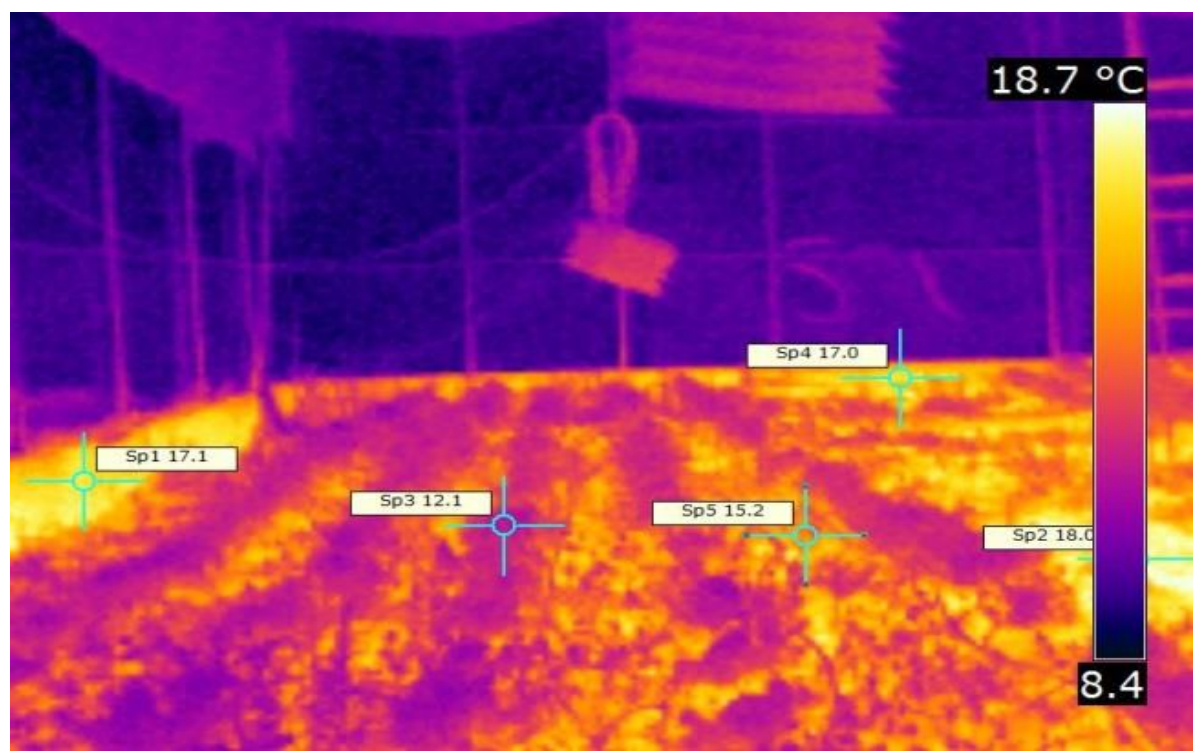

Şekil 8. Sera iç görünüm

Seralarda 1S1 kaybının bir kaynağı da sera yapı elemanları ve bunların neden olduğu istenmeyen açıklıklardır. Şekil 9'da çelik sera yapı elemanları üzerinde özellikle çatı bölgesinde sıcaklıkların yüksek olduğu görülmektedir (Şekil 9). 


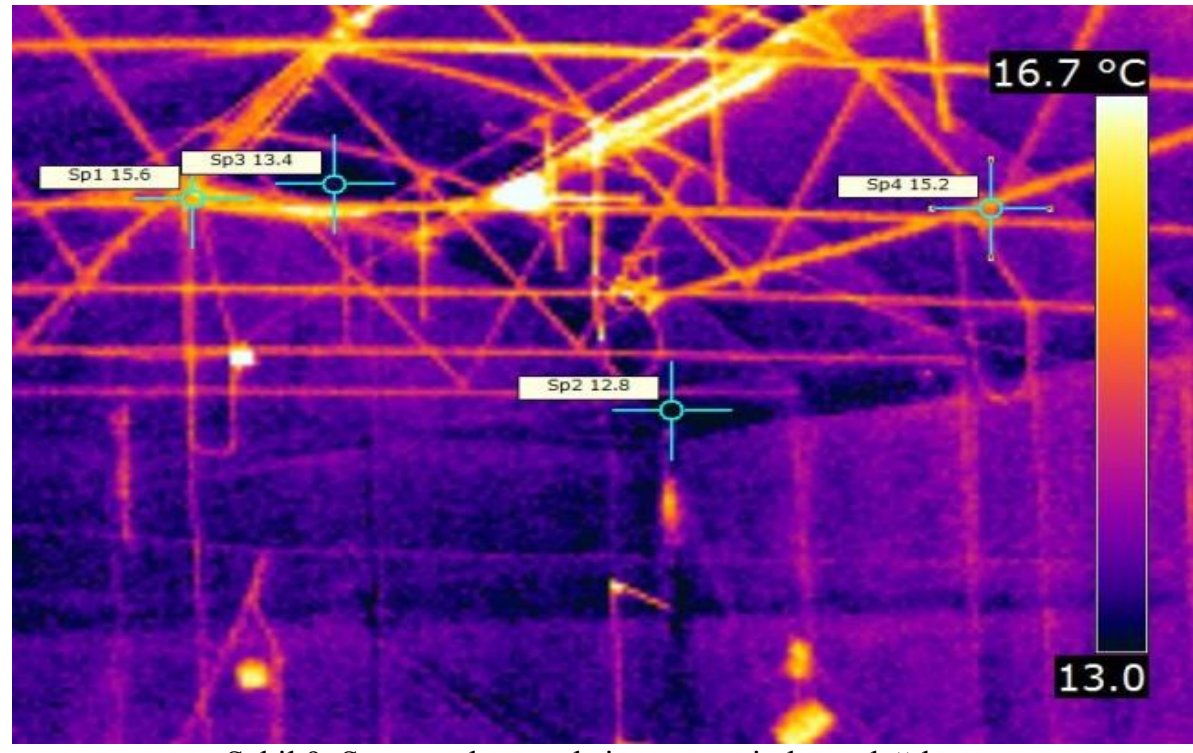

Şekil 9. Sera çatı konstrüksiyonu üzerinde 1 sı dağılımı

Analiz yazılımıyla yapı elemanları üzerinde maksimum sıcaklığın, çatıdan havalandırmalı serada, çatı havalandırma kapakları kenarında bulunan çelik profiller üzerinde olduğu belirlenmiştir. Havalandırma kapağının tam olarak kapatılmasına karşın çelik profillerin arasında yine de açıklık kaldığ 1 ve bu açıklıklardan dışarı doğru akan ısının bu noktadaki çelik profillerin ısınmasına neden olduğu görülmektedir. Sera iç ortamından daha yüksek sıcaklığa ulaşan bu yapı elemanları üzerinde depolanan 1sı, kondüksiyon yoluyla seradan ısı kaybı olușturmaktadır.

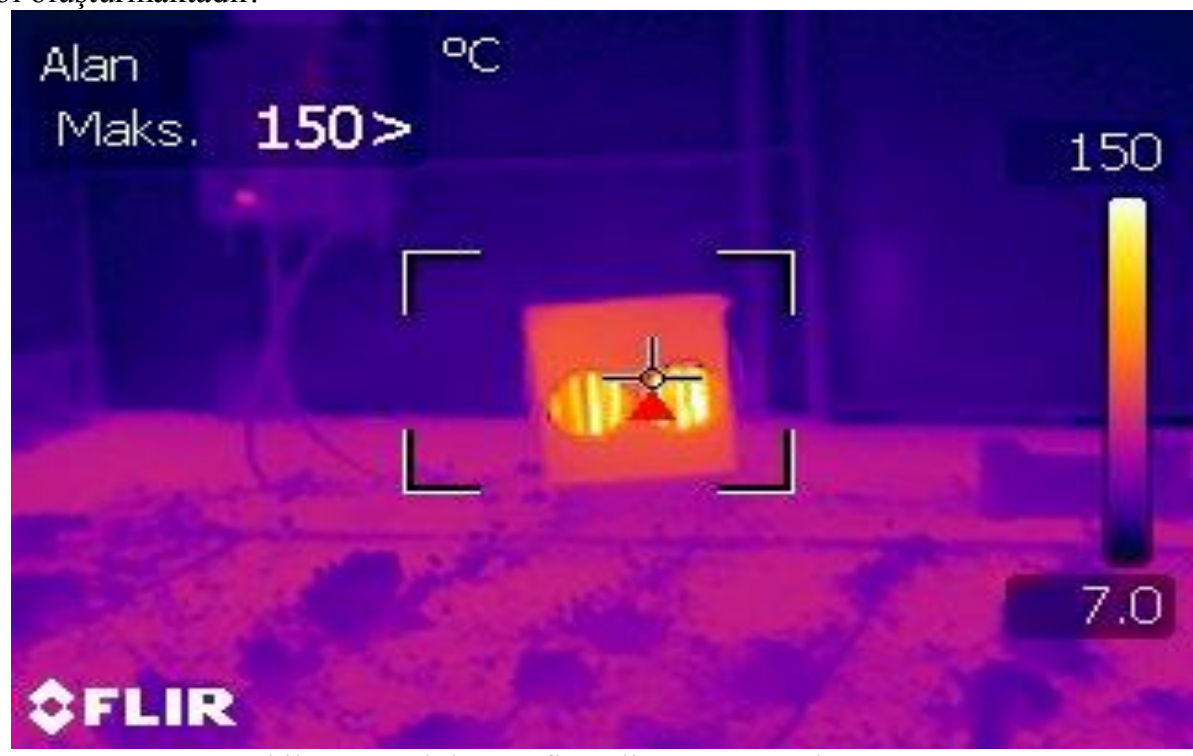

Şekil 10. Sıcak hava üflemeli 1sıtıcı termal görüntüsü

Isıtma yapılan serada bitki termal görüntüsü Şekil 11 'de verilmiştir. Termal görüntüde toprak sicaklığ 1 $17.8^{\circ} \mathrm{C}$ olarak ölçülmüştür. Bitkinin dış yaprak sıcaklığ ise $15.6{ }^{\circ} \mathrm{C}$, iç yapraklarındaki sıcaklık ise $14.3{ }^{\circ} \mathrm{C}$
Seradaki hava üflemeli ısıtıcının çalışır durumdaki termal görüntüsü Şekil 10'da verilmiştir. Buna göre termal isıtıcının rezistanslarındaki sıcaklığın $153{ }^{\circ} \mathrm{C}$ olduğu, $2 \mathrm{~mm}$ çelik sacdan imal edilen dış kasasındaki sıcaklığın ise $48{ }^{\circ} \mathrm{C}$ olduğu analiz yazılımıyla belirlenmiştir. Çekim mesafesi $4 \mathrm{~m}$ olan bu termal görüntüde, yerden $60 \mathrm{~cm}$ yüksekte bulunan hava çıkış açıklıklarının üfleme mesafesi içerisinde toprak sıcaklığında herhangi bir farklılık görülmemiştir. olduğu belirlenmiştir. Termal görüntünün alındığı saat 04:45'de sera iç sıcaklığ 1 ise $17{ }^{\circ} \mathrm{C}$, oransal nem ise $\%$ 60 olarak ölçülmüştür. 


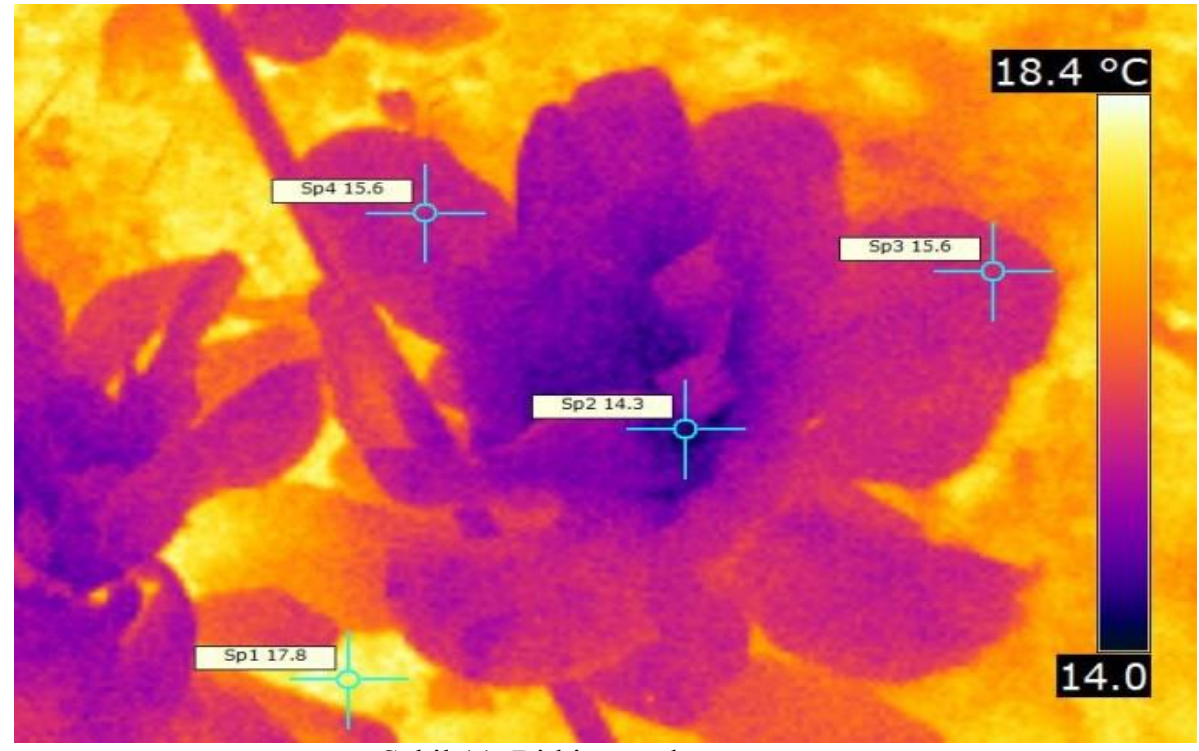

Şekil 11. Bitki termal görüntüsü

Toprak sıcaklığının iç sıcaklıktan yaklaşık $1{ }^{\circ} \mathrm{C}$ daha yüksek olduğu, bundan dolayı sera zemininden kaynaklanan 1S1 kaybının olmadığı anlaşılmaktadır. Ayrıca bitki dış yaprakları iç yapraklardan $1.3{ }^{\circ} \mathrm{C}$ daha yüksek olması 1sıtma sistemi ile 1sınan sera havasının bitkinin dış yapraklarındaki ısının yükselmesine neden olduğunu göstermektedir.

\section{SONUÇ ve ÖNERILER}

Termal kameralar, insan gözüyle görülemeyen, cisimlerin yaydığı termal radyasyonu algılayarak, son derece düşük 1s1 farklılıklarını bile görüntüleyebilmektedirler. Günümüzde elektrikli donanımları denetlemek, sağlık ve savunma alanında, binaların 1sı yalıtım durumunun belirlenmesi gibi birçok alanda kullanılmaktadır.

Termal kamera ile çekilen görüntülerde çok açık renkler sıcak, koyu renkler ise soğuk noktaları göstermekte, bu şekilde elde edilen görüntü üzerinden hangi bölgelerin sicak, hangilerinin soğuk olduğu belirlenebilmektedir. Termal görüntü işleme yazılımlarıyla istenilen renk tonlarına da dönüştürülebilen görüntüler üzerinde detaylı analiz yapılabilmekte ayrıca sayısal görüntü işleme yazılımları veya MATLAB gibi altyapılar kullanılarak geliştirilecek yazılımlarla da sayısal olarak analizlerinin yapılması mümkün olabilmektedir.

Termal kamera ile alınan görüntüleri analiz eden yazılımlar cismin ne tür bir cisim olduğunu tespit edemediğinden, bu tür yazılımlarda daha kesin sonuçlar alabilmek için, görüntüsü alınan ortamdaki malzemelerin 1s1 yayım katsayısının bilinmesi ve analiz yazılımına düzeltme faktörü olarak tanımlanması gerekmektedir.

Sicak hava üflemeli 1sitıcı ile 1sitılan bir seradan alınan termal görüntüler ile 1sı yalıtım durumunun ve 1s1 kaybının belirlenmesinin mümkün olduğu bu çalışma ile ortaya konmuştur. Analiz sonucunda seralarda 1s1 kaybının en fazla kap1 altları ve kenar boşlukları, havalandırma penceresi kenarlarındaki açıklıklarda ayrıca örtü malzemesinin çatı-ön duvar ve çatı yan duvar birleşim noktalarında olduğu görülmüştür. Bunun yanında yalıtım yapılmamış ve toprak üstünde kalan sera subasman betonunun sera içi ile dış ortam arasında bir 1sı köprüsü oluşturduğu ve buralardan da 1sı kaybının oluştuğu görülmüştür.

Serada 1sıtma yapıldığında, sera konstrüksiyonu üzerinde de 1s1 depolandığı termal görüntülerden anlaşılmaktadır. Depolanan bu ısının örtü malzemesi ile temas eden noktalarından kondüksiyon yoluyla 1sı kayb1 oluştuğu görülmektedir. Sera yap1 elemanlarının mümkün olan en küçük boyutlarda projelenmesi ve sera örtü malzemesi ile temas eden noktalarının azaltılması veya yalıtılmasıyla 1s kayb1 azaltılabilir.

Gündüzleri sera içerisinde oluşan yüksek sıcaklık ile sera toprağında 1 sı depolandığı alınan görüntülerde sera zeminindeki yüksek sıcaklıktan anlaşılmaktadır. Bu şekilde kazanılan ısının, sera 1sıtma ihtiyacının daha doğru bir şekilde belirlenmesi için hesaplamalarda dikkate alınması gerekmektedir.

$\mathrm{Bu}$ çalışma, binalarda ısı yalıtımın etkinliği ve isı kayıplarının belirlenmesi amaciyla son yıllarda yaygın bir şekilde kullanılan termal görüntüleme yönteminin, özellikle 1sıtılan seralarda 1sı tasarruf önlemlerinin etkinliği ile 1sı kayıp noktalarının belirlenmesi ve sera içinde ısı dağılımının görüntülenmesi amaciyla da kullanılabileceği göstermiştir.

\section{KAYNAKLAR}

Astarita, T., Cardone, G., Carlomagno, G. M. 2000. A Survey On Infrared Thermography For Convective Heat Transfer Measurements. Optics Laser Technology, 32 (7-8):593-610. 
Aldrich, R.A., Bartok, J.W. 1989. Greenhouse Engineering. NRAES-33, 66, The Northeast Regional Agricultural Engineering Service, Cornell University, Ithaca, N.Y. 14853.

Baille, A., López, J.C., Bonachela S., González-Real M.M., Montero J.I. 2006. Nightenergy Balance In A Heated Low-Cost Plastic Greenhouse. Agriculturaland Forest Meteorology, 137(1-2):107118.

Baytorun, N. 1996. Seralar. Ç.Ü. Ziraat Fakültesi Genel Yayın No: 110, Ders Kitapları Yayın No: 29, (Çeviri), Adana, 406s.

Carlomagno, G.M., Cardone, G. 2010. Infrared Thermography for Convective Heat Transfer Measurements. Exp. Fluids, 49 (2010): 1187-1218.

Carlomagno G.M., Cardone G., Meola C., Astarita T. 1998. Infrared thermography as a tool for thermal surface flow visualization. Journal of Visualization, 1:37-50.
Çalışan, M., Türkoğlu, İ. 2011. Termal Kameralar ve Uygulamalar1, Elektrik-Elektronik Bilgisayar Sempozyumu (FEEB 2011),46-50, Elazı̆̆

Değirmenci, A.İ. 2010. Türkiye'de Uygulanan Yalıtım Tekniklerinin Araştırılmasında Termal Kameranın Etkin Biçimde Kullanılması. Sakarya Üniversitesi, Fen Bilimleri Enstitüsü Yapı Eğitimi Anabilim Dalı. Yüksek Lisans Tezi, 184 s.

Giacomelli, G.A., Roberts, W.J. 1993. Greenhouse Covering Systems. Hort Technology, 3:50-58.

Meola, C., Maio, R. D., Roberti, N., Carlomagno, G. M. 2005. Application of infrared thermography and geophysical methods for defect detection in architectural structures. Engineering Failure Analysis, 12(6): 875-892.

Thomann, H., Frisk, B. 1968. Measurement Of Heat Transfer with an Infrared Camera. International Journal of Heat and Mass Transfer. 11(5):819-826.

Yağcioğlu, A. 2009. Sera Mekanizasyonu. Ege Üniversitesi, Ziraat Fakültesi Yayın No:562, Bornova, İzmir,64s. 